\title{
THE REVIVAL OF CONTACT POINTS AS A FORM OF PARTY LEGITIMATION IN CONTEMPORARY CHINA
}

\author{
Xinye $W^{a}$ and Adam Tyson
}

\begin{abstract}
One important but understudied political reform under President Xi Jinping since 2012 is the revival of contact points (lianxi dian) as a means for Chinese Communist Party (CCP) cadres to establish and maintain close ties with specific constituencies. The revival of contact points has the potential to disrupt dominant patterns of patronage in China and to enhance Party legitimacy. We analyse government claims about the impact of cadre contact points on national Party discipline and personnel, as well as on grassroots poverty reduction schemes and anti-corruption initiatives. Drawing on official sources, we find that contact points are framed as pragmatic government reforms with limited connection to Party ideology. The current reforms in China combine traditional state investigative powers and bureaucratic imperatives with heavily circumscribed channels for civic engagement. Party cadres appear to be given degrees of freedom to take their own policy initiatives at contact points, which create risks, but generally serve to legitimize the CCP.
\end{abstract}

Keywords: Chinese Communist Party, political legitimacy, contact points, corruption, poverty.

\section{INTRODUCTION}

The Chinese Communist Party (CCP) under the contentious leadership of Xi Jinping has undergone significant changes since 2012. One of the less-known political reforms introduced under the current regime has been the revival of contact points (lianxi dian) as a means for Party cadres to establish close ties with the public. In the 1960s, under Mao Zedong's autocratic rule, contact points were less endearingly referred to as "squatting points" (dun dian) that were supposed to serve as a bridge between Party officials and the public. Cadres were given a range of investigative powers in the hope of improving governance and to purge the Party of so-called reactionary elements that were jeopardizing the party-state. Since 2012, there has been renewed interests in contact points which, according to official accounts, now denote a place or space where Party officials can both investigate and serve the public. Given the problems of judicial interference, censorship, deficits in accountability, participation and representation in

\footnotetext{
a Xinye Wu is a Professor at the Hubei Engineering University, Chutian Scholar; East China University of Political Science and Law, China. Email: wuxinye@ecupl.edu.cn

b Corresponding Author: Adam Tyson is an Associate Professor of Southeast Asian Politics at the School of Politics and International Studies, University of Leeds, UK. Email: a.d.tyson@leeds.ac.uk
} 
China, contact points have the potential to play a key role in Party governance at the grassroots (jiceng) level by connecting cadres to local constituents, and thus improving government performance. There is a pressing need for the CCP to redress the "local legitimacy deficit" that results from the inability, both real and perceived, of local officials to live up to the reform rhetoric and political promises of central leaders (Dickson, Shen \& Yan, 2017, p. 126).

Contact points exist within a complex political network of national, provincial and local level cadres, and the government claims to be making use of new contact points to reduce tensions within the Party, as well as conflicts between cadres and the public (guan min jinzhang guanxi). Cadre and personnel management in China have been a source of corruption and factionalism that result from the overconcentration of power. It is generally understood that "decisions about the promotion of civil servants and the use of financial resources rest with high-level authorities who are not sufficiently supervised", which deters professionalism and meritocracy, and creates room for nepotism and corruption (Ko \& Weng, 2012, p. 722). In many cases, decentralization only serves to reproduce these conditions at local levels where patronage networks (wangluo) distort competition for personnel appointments and promotions in rural settings throughout China (Hillman, 2014, p. 106).

In this article, we examine a range of new structural channels for civic engagement, or what we call constructive spaces (jianshe kongjian), that are emerging in grassroots (township and village) China. We find that contact points are expanding to such an extent that they now include a network of enterprises, universities, hospitals, and various types of non-governmental organizations. From our review of Chinese language scholarship, media and government documents, the revival of contact points has the potential to disrupt dominant patterns of patronage in grassroots China, as well as to enhance Party legitimacy. Specifically, we find patterns of official claims about the impact of cadre contact points on national Party discipline and personnel, as well as grassroots poverty reduction schemes and anti-corruption initiatives. Though we do not have the evidence to substantiate all of these claims, there is at least an indirect causal link between the expansion of contact points and the developments that are occurring at subnational levels.

\section{CCP CADRES: FROM HIERARCHICAL BUREAUCRATS TO RESPONSIVE OFFICIALS}

The CCP faces complex challenges related to party discipline and corrupt officials, and there are (privately held) concerns surrounding the prospect of Xi Jinping staying in office beyond 2022. And yet, the Party seems to enjoy high levels of popular support, in part because of its recent effort to engage in direct consultation with the public and civil society organizations (Dickson, 2016, pp. 1-2). Research suggests that during the $\mathrm{Xi}$ Jinping era there has been a narrowing of space for cadres to exercise discretionary power, coupled with a tightening of ideological control by the state (Chen, 2018, p. 
300). While this is true, there is also a paradoxical situation emerging in which cadres are creating new spaces for local engagement with constituents, which indicates a move away from hierarchical relations with more responsive, entrepreneurial roles for CCP cadres.

The current leadership of the CCP, a party with some 88 million members and 3.5 million cadres, is concerned with growing inequality, social unrest and negative public perceptions of the CCP's internal politics. In Xi Jinping's first presidential address during the 18th Party Congress in December 2012 he focused on the need to combat corruption. By 2014, the executive Politburo Standing Committee removed more highranking officials "than their predecessors had in the previous ten years combined" ( $\mathrm{Li}$, 2016, p. 448). The crackdown on corruption was followed by the announcement of a new "mass line" (qunzhong luxian) political campaign to discipline the Party and strengthen ties between the Party and the people. The mass line is rooted in Marxism and the Soviet experience. The basic concept is "from the masses, to the masses", and during Mao's era, this took on an organization form, where the Party had to be internally cohesive (maintaining discipline within its ranks) while ensuring close ties between Party cadres and the masses (Hammond, 1978, p.5).

In May 2013, the CCP issued new regulations for mass line politics and contact points for national, provincial and local officials. ${ }^{1}$ Prior to the Xi Jinping era, contact points existed to provide Cadre training, to connect the Party to the people and to set guidelines for the investigative powers enjoyed by cadres. While these core functions remain, the regime under Xi Jinping introduced procedural and substantive changes. For example, in the past, senior cadres selected their own contact points and determined, rather informally, the length of time that they would spend at these contact points, but these procedural issues are now determined centrally by the CCP Organization Department according to strict guidelines to limit local variance. Substantive changes have also been made, for instance, with cadres now empowered to participate (play a leadership role) in grassroots governance and development, to initiate anti-corruption and poverty reduction programmes, with greater career incentives tied to performance.

In 2015, the National People's Congress began a reform experiment (xian xing xian shi) with the establishment of four new legislative contact points in Xiangyang City, Jingdezhen City, Lintao County, and Shanghai Hongqiao District to engage more directly with the public on legislative matters. One of the results from the public consultations in Shanghai Hongqiao was a revision to Article 5 of the 2015 AntiDomestic Violence Law to allow for the inclusion of the elderly alongside other vulnerable groups such as minors, pregnant women, disabled persons, and persons with serious illnesses. ${ }^{2}$

The architects of China's reform strategy since 2012 are attempting to strengthen the CCP's political networks through the inclusion of a wide range of actors from various sectors and organizations in China. At the centre of the network is the Party, 
acting as China's political hub as well as the "superego of society", with Party branches and committees setting local agendas and working to ensure that central decisions are implemented (Pieke, 2016, p. 22). The CCP is aware that its long-term survival depends in part on performance legitimacy and the popularity of cadres. In the view of the executive Politburo Standing Committee, cadres are a "key minority" (guanjian shaoshu) that play a central role in the Party's political network and in the country's political life. The risk for the Party is that if cadres grow too politically isolated or disconnected from the public, it could shake the very foundations of the CCP by undermining the Party's political legitimacy and identity.

Cadre training takes place primarily on the campuses of the thousands of Party schools (dang xiao) that are found at all levels in a vast nationwide school network. All CCP committees above county level (xianji) run their own Party schools, as do large state-owned enterprises. As prominent as their academic training is, the CCP also requires cadres to undertake practical training outside of the Party school system. The rationale is that cadres assigned to work or train at contact points can gain new competencies and benefit from experiential learning while avoiding some of the trappings of the Party school system, which is known to perpetuate patronage networks as well as irregular pathways to promotion (Lee, 2015, pp. 61-62). Recent grassroots reforms have limited the discretionary power of individual Party officials (such as provincial secretaries) over personnel appointments and have, to an extent, restructured cadre incentives, although regulatory loopholes allow for the persistence of informal and corrupt practices in China (Zeng, 2016, p. 74).

President Xi Jinping is attempting to selectively purge the CCP of corrupt elements and patronage networks while consolidating his own political power. He insists that "all Party organs and members should be frugal and make determined efforts to oppose ostentation and reject hedonism" (Xinhua, 2013). While the political purge continues to spread across provincial China, the CCP Central Committee claims to be overseeing a "thorough clean up" of undesirable work styles and methods in accordance with President Xi Jinping's instructions (Li Bin, 2014). In this context, the revival of contact points in China is part of the national effort to resolve four deeply entrenched political problems, known as the "four winds" (sifeng) in Chinese officialdom. According to the government, the four winds are formalism (xingshi zhuyi), bureaucratism (guanliao zhuyi), hedonism (xiangle zhuyi), and extravagance (shemi zhifeng). ${ }^{3}$

Bruce Gilley (2004, p. 126) compares formalism to procedural or technocratic processes that are blind to outcomes, and operate in a system that keeps the population at a distance from political processes. Bureaucratism, according to Mayfair Mei-hui Yang (1988, p. 414), refers to the over-centralization of authority, the shirking of responsibility, the overregulation of social activities, hierarchical status arrogance, the enjoyment of special privileges, the use of public office for private gain, and the obstruction of social initiatives from below. Hedonism and extravagance are selfexplanatory and do not require further definition. In the next section, we examine the 
politics of the "four winds" in the context of the CCP's reform pledges, particularly relating to cadre contact points, made during the 18th Party Congress in 2012.

\section{TAMING THE FOUR WINDS}

In the late 1970s, Deng Xiaoping began to step out of Mao's shadow by suggesting that it was perfectly acceptable for some in Chinese society to pursue great riches. Orville Schell (1984) captured the essence of this transformational process in his book To Get Rich is Glorious. The rise of a new class of high net worth individuals is a testament to the rapid economic growth rates that lasted for approximately three decades (19782008), but the current mood in Beijing seems more cautious and indecisive, with official announcements that it is time to accept a new normal defined by slower growth and economic rebalancing. Inequality is now a major flashpoint in contemporary China, and to appease regime critics and the public alike, Xi Jinping is putting his full support behind the national campaign against the "four winds" in both the public and private sectors (Zheng \& Chen, 2014).

The authoritarian Chinese party-state relies on cadres rather than electoral support to stay in power, and Party leaders attempt to strike a delicate balance by applying a technique known as "differentiated discipline" when dealing with cases of errant cadres, where some are tolerated, and others are punished (Cai, 2015, p. 4). In the effort to ensure strong party identification, the CCP focuses on officials within the system and deploys a range of rectification methods in the hope of making cadres "more submissive to the larger political goals of the Party centre" (Mertha, 2017, p. 65). In a new manifestation of mass line politics, the Central Discipline Inspection Commission (CDIC) recently established contact points in 13 provinces to strengthen the Party's internal discipline, while granting extensive investigative powers to local officials to enable the Party to respond more rapidly to public demands through its cadre networks (Yu, 2014).

Some scholars in China examine the problems of the four winds with reference to theories of Party construction (dang de jianshe), focusing on the CCP's self-help strategies that include efforts to learn from past mistakes and to develop new leadership strategies and approaches (Wang, 2010). To give one illustration of a new leadership approach, in 2013 the CCP Central Organization Department arranged for each of the seven members of the Politburo Standing Committee (PSC) to visit provincial contact points. The Party-controlled daily newspapers (dangbao) in each of the seven provinces visited by the PSC members adhered to strict reporting protocol, accentuating the positive outcomes that the visits apparently had on provincial governments and citizens.

President Xi Jinping chose to stay close to Beijing by visiting contact points in Hebei, a province with a rich political and dynastic history that now specializes in agribusiness and textile manufacturing. According to state media, Xi Jinping's visit led to investments in 12,000 new rural health clinics and budgetary approvals for rural 
infrastructure projects, particularly in waste disposal, costing approximately 16.4 billion yuan (Bie, Si \& Huo, 2014). Though it may just be party propaganda, CCP officials and press officers suggest that there is a positive correlation between the PSC provincial contact point visits and the immediate savings made as a result of the "six injunctions" (liu xiang jinling) listed by the government in December 2012. ${ }^{4}$ In the aftermath of President Xi's contact point visit in 2013, a series of high profile corruption cases have gripped Hebei province, leading to the expulsion of a number of senior officials from the Party. These include the former Provincial Secretary - Zhou Benshun, the former CCP Provincial Standing Committee member - Jing Chunhua, and Liu Xueku, the former Deputy Director of the Provincial Congress Financial and Economic Committee in Hebei.

According to local state-controlled media, Premier Li Keqiang's visit to Guangxi, an autonomous region in southern China, resulted in a 33 percent reduction in costs associated with international travel, entertainment (mainly hotels and banquets), and the purchase of luxury vehicles (Wei \& Bei, 2014). Based on his public statements, Li Keqiang is a strong proponent of "law-based governance" (yifa zhili) and he believes that Party legitimacy is inextricably linked to accountability and the rule of law (Tyson \& Wu, 2016, p.376). Similarly, a visit by China's fourth highest ranking official, Yu Zhengsheng, to the mining and agricultural province of Gansu (part of the former north Silk Road corridor), led to unconfirmed reports of a 40 percent reduction in provincial costs within six months (Xv, 2013), while former Politburo Standing Committee member Liu Yunshan's assignment in the coastal province of Zhejiang is said to have triggered a 26.6 percent reduction in official expenses (Ruan, 2014).

As the head of the powerful Central Discipline Inspection Commission at the time, Wang Qishan (2013) claimed that his efforts in the industrialized northeast province of Heilongjiang had led to 810 million yuan in public savings in 2013, in addition to 3,447 new anti-corruption cases and a general crackdown on illegality and abuses of public office. Heilongjiang represents a hard test of the CDIC, and China's leaders more generally, as the province has a reputation for endemic corruption, with cases of the buying and selling of public office for personal gain grabbing headlines in the 2000s, and cases of judicial corruption receiving negative press in the 2010s (Zhu, 2008; Zhang, Zhang \& Wu, 2016).

Former National People's Congress chairman Zhang Dejiang visited the coastal province of Jiangsu, just west of Shanghai, to enhance the demonstration effect of the CCP's contact point strategy. According to partisan state media sources, the Jiangsu visit resulted in proposals for the decentralization of over 200 administrative functions to improve provincial governance, as well as official spending cuts in international travel, hospitality costs and new vehicle purchases (Xinhua, 2014). Similarly, former Vice Premier Zhang Gaoli's efforts in Sichuan province, southwest China, led to partisan reports of a fall in government office expenditures and a modest reduction in the number of official provincial meetings held in the second half of 2013 (Fang \& 
Zhou, 2014).

The PSC members still serving in 2014 extended their official provincial tours by visiting county level contact points, investigating the conduct of lower ranking officials and offering advice to local citizens in a grand symbolic gesture of their commitment to government austerity, anti-corruption and public consultation (People's Daily 2014). Local cadre activities were investigated in seven counties: Lankao, Henan Province; Ongniud Banner, Inner Mongolia; Shanghang, Fujian Province; Wuding, Yunnan Province; Liquan, Shanxi Province; Mengyin, Shangdong Province; and Nongan, Jilin Province. This wide cartographic spread strengthens the Party's political networks and send a message that the Party's commitment to good governance extends to all bureaucratic levels and to all geographic locations.

\section{PUBLIC TRUST, PARTY DISCIPLINE AND PERSONNEL MANAGEMENT}

In her study of Chinese workers and labour unions, Jackie Sheehan (1998) identified the perennial problems of formalism and bureaucratism that are so strongly associated with the attitudes and workstyles of cadres. To paraphrase, cadres are too isolated from the grassroots (the rank and file), rely too heavily on coercive methods, show too little trust in ordinary workers and the public, and are too arrogant and high-handed (Sheehan, 1998, p. 14). In a related study, Pitman Potter (2001, p. 10) discovered a dichotomy in traditional Chinese society between official norms of hierarchy and popular norms of fairness that continues to influence Chinese legal and political culture today. While there is an understanding that the CCP needs to reform in order to improve its public standing, the Party continues to uphold Leninist principles such as democratic centralism and the Soviet-style nomenklatura system that determines personnel appointments and requires the absolute commitment of cadres to implement central Party policies (Chan, 2004).

The government has constructed a vast organizational network that extends from the centre to the grassroots level, and has gone about this in a highly bureaucratic and hierarchical manner to ensure that every Party member is included in an organization, and that every organization is centrally accountable. According to data from the Central Organization Department, by the end of 2015 there were some 4.4 million grassroots Party branch organizations nationwide, overseeing political activities in local communities as well as in schools, enterprises and non-governmental organizations. This complex multi-layered network is being reformed in the hope that cadres carry out their duties with greater transparency and public accountability, while at the same time increasing their capacity to monitor and control the Chinese public. Following this logic, patterns of "relational repression" have been identified in rural Zhejiang, where soft power control techniques are used by well-connected local authorities to prevent or defuse popular protests through a mixture of persuasion, compromise and concession (Deng \& O’Brien, 2013).

In addition to relational repression and various other "smart power" strategies, the 
current political networking and public outreach campaign being conducted by cadres at national and local contact points is designed to shore up the legitimacy of the Party through ideological appeals and intellectual propaganda. Taking the education sector for example, the Ministry of Education in Beijing is establishing contact points in all the provinces, municipalities and autonomous regions of China. In 2013, the Chinese Academy of Sciences, China's leading policy think tank, issued a call for each cadre to designate 2-3 scientific research institutes and universities as contact points. ${ }^{5}$ Further evidence of the expansion of contact points comes from the activities of state enterprises (zhongyang qiye), private enterprises (fei gong qiye) and non-governmental organizations (fei zhengfu zuzhi).

The State Grid Corporation of China (SGCC), a powerful state-owned utility company with approximately USD500 billion in total assets, now requires its leading Party group member cadres to select provincial and county branch subsidiary companies as their contact points. For instance, the deputy general manager of the SGCC, Yang Qing, has contact points in a subsidiary company in Hubei province as well as in a Zigui county branch of the corporation (SGCC 2014). The Red Cross Society of China, representing the non-state sector, also requires senior cadres to establish their own contact points, specifically one at provincial level, one at county level, and at least two at township level (Red Cross 2014). The idea is that spread of contact points and the creation of new constructive spaces will change the country's civic culture by challenging the traditional hierarchy that limits the opportunities for junior cadres to interact with senior cadres, and keeps ordinary citizens at a distance from officials at all levels. Cadres operating at contact points are in theory more willing to consult citizens and non-state actors on important development and governance issues, which is reminiscent of the consultative authoritarian model that allows for greater autonomy for a plurality of social actors while simultaneously expanding the mechanisms of state control (Teets, 2014, p. 97).

Within the growing network of contact points, one of the core functions carried out by cadres is to investigate and collect information to advise on the "true situation" (zhenshi qingkuang) at the grassroots level. The Party now expects cadres to use constructive spaces within contact points to conduct research and report on the nature and content of the appeals and complaints coming from the general public, creating a policy feedback mechanism. Cadres interact and communicate directly with the public to reverse the negative perceptions of the Party that are partially blamed for the rise in mass incidents (qunti xing shijian). According to estimates, there were approximately 84,000 mass incidents, defined as incidents involving ten or more people, recorded in the first half 2013, with 32.1 percent involving protests against the government (Zhang \& Chen, 2014). Beyond repression, the Party's response is to expand its network of contact points, opening new structural channels in order to improve governance, and resolve reputational problems by allowing more direct communication between local authorities and communities. ${ }^{6}$ It can be said that China, like neighbouring Vietnam, is searching for the right balance between repression and responsiveness in order to 
achieve good governance in the absence of democracy (Kerkvliet, 2010, p. 51).

In theory, the constructive spaces that are emerging at contact points serve the dual purpose of enhancing cadre loyalty to the Party while improving cadre competencies to deal with social, political and ideological problems at grassroots levels. Every cadre is now required to establish and manage contact points, which is essentially a large-scale state intervention into local affairs aimed at enhancing the legitimacy of the Party while increasing the scope for state surveillance. Cadres working part time within their contact point networks are responsible for three main objectives: investigation (information collecting), assistance (providing aid and ideological advice to people in need), and public communication. There is evidence of a change in the incentive structures for cadres assigned to contact points as well as the level of recognition given for work done at contact points, which has a bearing on performance evaluations and promotions (Zhou, 2016). Some Chinese scholars are now arguing that contact points are reducing the power imbalances that traditionally give senior cadres a high level of discretionary authority and cause political exclusion and social unrest (Li, 2015).

Contact points are an example of within system change, with new constructive spaces opening that enliven grassroots politics and enhance participation without undermining existing laws and institutions. We believe however, that some degree of risk is unavoidable. For example, there are questions about the ability and capacity of the CCP to enforce the regulations set out by the Central Organization Department regulations that are meant to limit cadre activities and control cadre behaviours. Some cadres will certainly find ways to increase their operational autonomy within specific contact points, leading to a greater likelihood of deviations from central policy and core Party ideology, and the prospect of developments at grassroots levels that are attributable to specific cadres rather than the CCP. With these risks and opportunities in mind, we examine state media representations of some recent contact point initiatives related to poverty alleviation and anti-corruption in the following sections.

\section{RURAL POVERTY ALLEVIATION}

China's rapid but highly uneven economic growth since 1982 has achieved some remarkable milestones, including the lifting of more than 50 million rural population out of poverty, but it has also created significant inequalities, including rural-urban gaps in wealth, infrastructure and public service provision (Yeh, O'Brien \& Ye, 2013, p. 916). One of the decisions at the Third Plenum of the 18th Party Congress in November 2013 was to "improve the incentive mechanism for the talented to move to community-level positions and areas with poor conditions". 7 Cadres are using contact points to design and deliver subnational development programmes, applying their local knowledge and grassroots networks to achieve economic targets in line with various "mandates from above" (Birney, 2014). Cadres are also responsible for assisting local communities in their applications for development projects and funding, and very often draw on their understanding of funding application procedures as well as their personal relationships with government officials and enterprises. 
Some local authorities are changing their approach to grassroots politics by introducing various innovations at contact points, for example the utilization of WeChat groups to communicate with, and assist the public while organizing investigations and issuing statements about new government policies. Changes are also noticeable in the populist measures being initiated by individual Party leaders. For example, Yu Xuewu, the Party secretary of Hongan County, Hubei Province, personally intervened in the case of 65-year-old Wei Zhengkai whose dilapidated house was in urgent need of repair. In 2013, Secretary Yu Xuewu applied for assistance under the National Rural Dangerous House Renovation Fund supported by the Ministry of Finance as well as local government financial subsidies for rural housing (Wu, 2014).

In addition to the special funding available from the central government, there are various poverty alleviation programmes and funds supported at provincial, prefectural, county, township and village levels. Under the poverty alleviation programmes (fupin xiangmu) that are administered by lower level state financial organs, money is being allocated to cadres who are designing programs for their specific contact points. This represents a departure from a system that has traditionally kept the population at a distance from political processes (Gilley, 2004, p. 126). More public money is now available to address livelihood issues (min sheng wenti), and some cadres are visiting and consulting with communities on a regular basis to make the best use of these funds to reduce poverty.

One new grassroots development is the "one-to-one" (jie dui zi) approach, meaning that cadres work directly with individual households or even individuals to resolve problems of provisioning and basic needs. The one-to-one approach is often applied in cases of poverty alleviation, where cadres are responsible for investigating and responding directly to local household needs. ${ }^{8}$ In some cases reported from Hubei province, the one-to-one approach has evolved into a one-to-three approach, where county-level cadres take responsibility for one elderly citizen ( wu bao hu), one stay-athome-child (liushou ertong) whose parents are away from the village, and one family in absolute poverty. The CCP is now promoting variants of the one-to-one approach throughout the whole of China in a bid to enhance legitimacy.

In Huaiyuan, an agricultural county in Anhui Province, 51 impoverished villages were identified by the government in 2015, and in response, the County Organization Department assigned 51 cadres to village contact points under the one-to-one approach in search of local development solutions (COD 2015). The farming communities of Huaiyuan traditionally grow wheat, corn and soybean, and many young people are leaving the county in search of employment opportunities in big cities. In what seems like a perfect symmetry, and therefore bound to raise suspicions, new development projects were promptly announced in all 51 village contact points in Huaiyuan, including seven agribusiness programmes with a combined investment of 2.68 million yuan and 18 infrastructure programmes with a total investment of 10.5 million yuan (COD 2015). 
The story is similar in Hongan, a county in Hubei Province, where the mountainous terrain is better suited to fruit trees and local communities, are even poorer than those in Huaiyuan. Cadres are attempting to slow the rate of youth emigration in Hongan while devising farm aid schemes that include seed projects and high yield crop techniques, approving new roadworks and infrastructure upgrades, and attempting to strengthen the role and capacity of village committees. In Yangshan, a more industrialized county with mining and manufacturing sectors in Guangdong Province, the one-to-one approach has reportedly been implemented in all 167 county contact points to provide financial assistance to poor families, with an estimated 2 million yuan being distributed by cadres in the second half of 2014 (Huang, 2014).

To reduce tensions between cadres and their constituents, the local CCP Committee in Wuhu City, Anhui Province, requires cadres to make use of contact points to work directly with individual families. Cadres must visit families at their local contact points at least once per month and must stay at their local contact points for at least ten days per year. The 2014 program achievements of cadres across 247 contact points in Wuhu are summarized by state media as follows: $470 \mathrm{~km}$ of new rural roads constructed, along with over $400 \mathrm{~km}$ of irrigation canals and ditches, and more than 160 bridges and culverts, at a total cost of some 3 million yuan (Gao, 2013). The approach in Wuhu is known as a "double contact" method because cadres are embedded in bureaucratic state organs as well as local community networks, and the method is supposed to produce a double dividend by reducing the social divisions and tensions that are associated with formalism and bureaucratism (Gao, 2013).

\section{ERADICATING LOCAL CORRUPTION THROUGH GRASSROOTS ENGAGEMENT}

In his book Double Paradox, Andrew Wedeman (2012) considers how and why China experiences worsening corruption while maintaining rapid economic growth. The follow up (and still unresolved) question is whether this situation is sustainable. One consequence of political corruption in China is the considerable variance in the quality of governance across rural settings. It is generally accepted that the lack of participation, accountability and transparency in rural areas is one of the causes of mass incidents and tensions between cadres and the public. Contact points are designed to create new structural channels and constructive spaces to improve grassroots governance and service provision that supplements rather than replaces the current bureaucratic system. Cadres are strictly supervised by the CCP Organization Department, but still have some scope for innovation as well as deviation, creating opportunities for good governance as well as the risk of new forms of grassroots corruption emerging.

Anti-corruption education is one of the core tasks assigned by the Central Discipline Inspection Commission (CDIC) to contact points. For example, new primary school initiatives have been established in contact points in Harbin City, Heilongjiang 
Province, and secondary school initiatives in Chengdu, Sichuan Province. During a "contact point" tour of primary schools in Harbin in May 2011, for instance, the Deputy Secretary of the CDIC, Yubin Li, sought to raise awareness about corruption, claiming that "it is a positive start for the children. When they grow up, or [if they] grow up to be a cadre, these experiences will help them reject corruption" (CDIC 2011, p. 1). In addition to public education, we found that four county-level administrative initiatives have recently been used to raise awareness about Party discipline, focusing on community outreach efforts in Guangzhou and Xiamen, and highlighting anticorruption investigations at the Jiangsu Provincial Revenue and Tax Bureau as well as in the private sector, with the Wanxiang Group (automotive) being targeted by the CDIC. ${ }^{9}$

As part of the broad reforms associated with the revival of the contact point system, cadres are being assigned supervisory roles at local contact points to identify and eradicate corrupt practices. This is part of the wider CDIC policy of targeting Party leaders known as "tigers" (lao hu), as well as lower-ranking officials at grassroots levels known as "houseflies" (cang ying) whose malfeasance can cause reputational damage to the Party as well as direct harm to local communities (Guo, 2014, p. 614). In grassroots China, it is common for low-ranking officials to abuse their power for private gain. This includes the cadres in charge of agriculture-related tax breaks, subsidies and microfinancing programmes, as well as rent-seeking village officials who exchange land permits for bribes and manipulate development aid and relief assistance funds (State Council 2011). According to official statistics, there were 171 corruption cases involving local authorities in 2013 involving losses of more than 2.2 billion yuan ( $\mathrm{Li}$ Zhangjun, 2014).

The Chinese term ti min zuo zhu refers to the traditional tendency for cadres to carry out their grassroots work without the knowledge or consent of the public. In China, cadre preferences are often shaped by their ambitions, political connections and career trajectories. To be active and productive (zuo dian shi), some cadres govern by coercion rather than consent, for example making unilateral decisions and passing instructions to local grassroots officials without any public debate as to the merit or necessity of the government projects being earmarked, funded and implemented. Some within the CCP's central leadership are now openly criticizing this type of grassroots governance and expect that the collaborative networks arising out of contact points will improve public confidence in the Party by increasing participation and accountability.

There are numerous cases of mismanagement resulting from the personal ambitions and corrupt practices of cadres in rural China. Chinese media is replete with stories about ghost cities, land appropriation and irregular spatial planning, for example where school buildings are constructed in catchment areas with insufficient numbers of students, resulting in empty or underutilized buildings. These types of distorted decisions are sometimes categorized by Chinese observers as performance programmes (zhengji gongcheng) or face programmes (mianzi gongcheng) serving the interests of 
individual cadres. In Meizhou City, Guangdong, for example, there are accusations of corruption being levied against local "housefly" officials, including village Party secretaries, village directors and members of village committees, involving losses of up to 100,000 yuan (Liu, 2016). In 2012 in Zhanyi County, Yunnan Province, the local Discipline Inspection Commission registered 169 corruption cases, 115 of which involved village officials (Yang, 2015). These examples are indicative of a general pattern of malpractice across rural China, and a newfound willingness of the state to prosecute.

In rural China, the authority for land sales and transactions rests with the local (township, village) committee, although in practice Party secretaries often make unilateral land use decisions without the consent of local committees, bypassing local citizens' right to know (zhi qing quan). In one high profile case in 2011, the citizens of Wukan, a wealthy village in Guangdong Province, revolted against their corrupt, land grabbing Party Secretary Chang Xue (Han, 2013). As many as 4,000 villagers, led by Lin Zuluan, mobilized and ousted the village committee from power, and established their own (short-lived) Provisional Council of Village Representatives to serve as an alternative to the existing system. Rising unrest in the countryside prompted Wang Qishan, who was the head of the Central Discipline Inspection Commission at the time, to prioritize the issue of grassroots corruption in 2013. At a December 2015 CCP Central Rural Work Conference in Beijing, anti-corruption in rural China was included on the agenda, focusing on the expropriation of land and misuse of agricultural funds and subsidies, as well as the need for poverty alleviation and development (People's Daily 2016).

To reduce corruption and increase accountability, contact points are used by the Chinese government as a means by which to implement a fully functioning system of checks and balances under the supervision of the CCP's Organization Department. There is evidence from communities in Harbin City, for example, that consultative processes between people and their Party representatives are reducing conflicts and protests, and improving local decision-making and policy outcomes (Wang, 2014). County-level cadres enjoy degrees of discretion and latitude that allow them to design and implement policies according to local conditions (Heberer \& Trappel, 2013, p. 1050). Contact points are also being used to create new petition routes for the public to provide anonymous tip-offs and reports about bribery and corruption at the grassroots level. China has a strict hierarchical petition system that lacks transparency and leaves many problems unresolved, so the public can now, in a sense, bypass this dysfunctional system by going directly to contact points to appeal to their local Party representatives. The CCP seems to be endorsing the logic of "citizens as clients" within an emerging model of authoritarian responsiveness that allows for the collaborative provision of public services and the co-production of public policy (Vigoda, 2002, p. 528). 


\section{CONCLUSION}

In this article, we examined the ways in which contact points are represented in Chinese language media, scholarship and government documents. Contact points appear to be creating new structural channels and constructive spaces (jianshe kongjian) through which CCP cadres investigate and manage developments at the grassroots level. We considered the types of innovations and achievements that are occurring at contact points (lianxi dian) throughout the vast Party patronage network (wangluo), and queried the extent to which contact points are becoming another source of CCP legitimacy. We then examined the uncertainties arising from the expansion of contact points at the grassroots (jiceng) level. We conclude that contact points run in parallel with the existing bureaucratic structure and create a networking mechanism that generates new interactions between Party cadres, enterprises, educational institutions, social organizations, and local grassroots constituents as part of China's evolving, post-2012 fragmented authoritarian model of governance.

The expectation of some reformists within the CCP is that contact points will help reduce corruption by ensuring that official selection and promotion channels are widened, leading to improvements in collaborative governance, poverty reduction strategies, and communications between Party officials and the public. The fact that cadres are increasingly accessible and are working to specific targets in specific contact points means that their performance can be evaluated, they are more publicly accountable, and they have more freedom to develop new initiatives. While enjoying a degree of freedom to operate at their contact points, cadres are still required to report directly to local CCP committees that are responsible for imposing constraints and maintaining discipline and order.

The contact point system is designed to enhance the CCP's legitimacy, but it also causes a degree of uncertainty for the ruling party. Contact points are supported by law as well as numerous internal Party documents and regulations, although there are concerns about mission creep, by which we mean the expansive and at times disruptive nature of the grassroots work taking place at local contact points, and the evolving role played by cadres who have more freedom to take initiative and innovate. One specific issue that warrants further research is the risk that individual cadres who are working in partnership with, and are directly accountable to, local constituents, will take credit for policy innovations and positive developmental outcomes, leaving the Party behind.

Considering the risks and uncertainties associated with the current reforms, the CCP's continued support for, and investment in, contact points relates to ongoing efforts to control the Party to remain viable in a country experiencing rapid economic, social and political change. Contact points are part of a pragmatic government reform programme with limited substantive connection to state ideology. We are witnessing an emerging form of network politics that includes the creation, use and abuse of 
constructive spaces at the grassroots level. The current reforms combine traditional CCP investigative powers and bureaucratic imperatives with new structural channels for civic engagement, where cadres are given a degree of freedom to take their own initiative at contact points, contributing to an increasingly contentious social and political landscape in China.

\section{ACKNOWLEDGMENT}

The research for this article is supported by the National Philosophy and Social Science Foundation of China (Grant No. 2014BZZ006) and the China Scholarship Council (Grant No. 201508310047).

\section{NOTES}

${ }^{1}$ According to government document Zhong Fa [2013] No.4 entitled "Zhonggong zhongyang guanyu zai quan dang shenru kaizhan dang de qunzhong luxian jiaoyu shijian huodong de yijian [The CCP Central Committee's Opinions for Carrying Out the Mass Line Educational Practice Campaign]".

2 Yingting Chen, "Ben shi queli shoupi shi ge jiceng lifa lianxi dian [Shanghai Establishes Ten Legislative Contact Points at the Grassroots]" Shanghai Law Journal (14 June 2016), at $<$ http://newspaper.jfdaily.com/shfzb/html/2016-06/14/content_198677.htm>.

3 Thomas Heberer, 2014, p. 119, discusses the same government policy but, in a slight misinterpretation, refers to the "four evils" instead of "four winds" and mistakenly lists corruption (fubai) instead of formalism (xingshi zhuyi).

${ }^{4}$ At the start of the 18th Party Congress in December 2012 the government campaigned against the eight provisions (ba xiang guiding), the six injunctions (liu xiang jinling), and the four winds (sifeng). Restrictions were first imposed on central Politburo members and then extended to all Party cadres to limit public spending and the abuse of power by officials by restricting overseas travel and cutting back on receptions, banquets, luxury hotels and cars, and all forms of gift giving. See Brødsgaard and Grünberg (2014).

${ }^{5}$ According to the Chinese Academy of Sciences document Ke Fa Dang Zi [2013] No.15 entitled "Zhongguo kexueyuan shenru kaizhan dang de qunzhong luxian jiaoyu shijian huodong zongti shishi fangan [The Overall Programme Implementation Plan of the Party's Mass Line Education Practice in the Chinese Academy of Sciences]".

${ }^{6}$ For an example from Shanghai see document Chang Qun Ban Fa [2014] No.1 entitled "Guanyu jianli changning qu dang de qunzhong luxian jiaoyu shijian huodong quwei changwei, dangyuan fu quzhang lianxi dian de tongzhi [The Notice of the Establishment of Contact Points for Standings Members of the CCP Changning District Committee and Deputy Chiefs]".

7 According to the 2013 CCP Central Committee decision entitled "Zhonggong zhongyang guanyu quanmian shenhua gaige ruogan zhongda wenti de jueding [Decision of the Central Committee of the Communist Party of China on Some Major Issues Concerning Comprehensive Reform]".

${ }^{8}$ According to the State Council of the PRC, people with annual earnings of less than 2,300 yuan are impoverished. The State Council refers to the World Bank's 1.25 dollars per day poverty line, and a nutritional standard that calls for a minimum daily intake of 2,100 calories. 
9 The Central Discipline Inspection Commission does not give specific reasons for their targeting of the Wanxiang Group. What we do know is that Lu Guanqiu, the former CEO of Wanxiang, is a highly regarded private entrepreneur in China who is politically well connected and serves as the CCP Committee secretary for the Wanxiang Group.

\section{REFERENCES}

Bie, Z., Si, J. \& Huo, X. "Jianding lixiang xinnian, qieshi zhuanbian zuofeng [Sticking to ideology and beliefs, thoroughly transforming governance]", (2014, January 23), Hebei Daily. Retrieved from http://hbrb.hebnews.cn/html/201401/23/content_10957.htm

Birney, M. (2014), Decentralization and veiled corruption under China's 'rule of mandates'. World Development, 53, 55-67.

Brødsgaard, K. E. \& Grünberg, N. (2014), The fourth plenum of the CPC makes an important decision on law reform in China. The Copenhagen Journal of Asian Studies, 32, 2, 122-130.

Cai, Y. (2015). States and agents in China: Disciplining government officials. Stanford CA: Stanford University Press.

CDIN. (2011, May 30). "Jiyibu jiaqiang fanfu changlian jiaoyu he lianzheng wenhua jianshe, wei fanfu changlian jianshe tigong sixiang baozheng he wenhua zhichi [To further strengthen anti-corruption education to provide an ideological basis and cultural support for anti-corruption]. China Discipline Inspection Newspaper.

Chan, H. S. (2004), Cadre personnel management in China: The nomenklatura system, 1990-1998. The China Quarterly, 179, September, 703-734.

Chen, X. (2018), Remaking the loyal cadres: The ideological responsibility system in China's new era. Journal of Chinese Governance, 3, 3, 292-306.

Chen, Y. (2016), Ben shi queli shoupi shi ge jiceng lifa lianxi dian [Shanghai establishes ten legislative contact points at the grassroots]. Shanghai Law Journal, June, Retrieved from http://newspaper.jfdaily.com/shfzb/html/201606/14/content_198677.htm

COD. "Ganbu zhudian lianxi pinkun cun zhidu tuidong jingzhun fupin chu shixiao [Promotion of poverty village aid at contact points results in effective performance]" (2015, December 29), CCP Central Organization Department. Retrieved from http://dwlm.12371.cn/2015/12/29/ARTI1451379711040827.shtml

Deng, Y. \& O'Brien, K. J. (2013), Relational repression in China: Using social ties to demobilize protestors. The China Quarterly, 215, September, 533-552.

Dickson, B. (2016). The Dictator's dilemma: The Chinese communist party's strategy for survival. New York: Oxford University Press.

Dickson, B. J., Shen, M. \& Yan, J. (2017), Generating regime support in contemporary China: Legitimation and the local legitimacy deficit. Modern China, 43, 2, 123155 .

Xiaohu, F. \& Zhou, Q. “Qianghua qunzhong guandian: cong sixiang zijue dao xingdong 
zijue [Focusing on the masses: From an emphasis on ideology to taking action]" (2014, January 20), Sichuan Daily, Retrieved from $<$ http://epaper.scdaily.cn/shtml/scrb/20140120/52586.shtml $>$.

Gao, D. “Tongguo 'shuang liangxi' miqie dang qun gan qun guanxi [Close connections between the party and its cadres and the masses by means of 'double contacts']" (2013, January 28), People's Daily, Retrieved from $<$ http://opinion.people.com.cn/n/2013/0128/c1003-20343184.html>.

Gilley, B. (2004), The 'end of politics' in Beijing. The China Journal, 51, 115-135.

Guo, X. (2014), Controlling corruption in the party: China's central discipline inspection commission. The China Quarterly, 219, September, 597-624.

Hammond, E. (1978), Marxism and the mass line. Modern China, 4, 1, 3-25.

Han, K. (2013), Zhongguo chengzhenhua fazhan de zuida fengxian: chengxiang maodun neihua [The political uncertainty of China's urbanization: Internal contradictions between urban and rural areas]. Journal of the Chinese Academy of Governance, 3, 4-8.

Heberer, T. (2014), China in 2013: The Chinese dream's domestic and foreign policy shifts. Asian Survey, 54, 1, 113-128.

Heberer, T. \& Trappel, R. (2013), Evaluation processes, local cadres' behavior and local developmental processes. Journal of Contemporary China, 22, 84, 1048-1066.

Hillman, B. (2014). Patronage and power: Local state networks and party-state: Resilience in rural China. Stanford, CA: Stanford University Press.

Huang, Y. "Guangdong Yangshan: 'siwei yiti' tansuo ganbu zhudian lianxi qunzhong gongzuo jizhi [Yangshan county, Guangdong province: Four innovative methods to help cadre contact points develop Further]" (2014, November 20), CCP Central Discipline Inspection Commission. Retrieved from $<$ http://jiaoliu.12371.cn/2014/11/20/ARTI1416467642747768.shtml>.

Kerkvliet, B. J. T. (2010), Governance, development, and the responsive-repressive state in Vietnam. Forum for Development Studies, 37, 1, 33-59.

Ko, K. \& Weng, C. (2012), Structural changes in Chinese corruption. The China Quarterly, 211, September, 718-740.

Lee, C. P. (2015). Training the party: Party adaptation and elite training in reform-era China. Cambridge: Cambridge University Press.

Li, Bin. "Yi zhili fazhi hua chanchu cunguan fubai [Eradicating corruption among village officials by governing according to the rule of law]" (2014, November 5), People's Daily. Retrieved from <http://gd.people.com.cn/n/2014/1105/c12393222813748.html>.

Li, L. (2016), The rise of the discipline and inspection commission, 1927-2012: Anticorruption investigation and decision-making in the Chinese communist party. Modern China, 42, 5, 447-482.

Li, Y. (2015), Dianxing zhili: guojia yu shehui de fenli, yiju lingdao lianxi dian de fenxi [Governance by models: The separation of state and society based on the analysis of cadre contact points]. Journal of Nanjing Agricultural University (Social Science Edition), 3, 101-109.

Li, Z. "Ba lianxi dian bancheng shifan dian [Constructing the contact Point model]" 
(2014, July 10), People's Daily. Retrieved from $<$ http://politics.people.com.cn/n/2014/0926/c1001-25737834.html>.

Liu, S. "Jiaqiang gaige fazhan cuoshi, dujue nongcun ganbu fubai: Guangdong Meizhou zhongyuan guanyu cun ganbu zhiwu fanzui anjian de diaocha baogao [Strengthening reform and development measures, putting an end to rural village official's corruption: A report on village officials duty crime cases in Meizhou city, Guangdong province]", (2016, February 18), People's Court News. Retrieved from $\quad<$ http://rmfyb.chinacourt.org/paper/images/201602/18/08/2016021808_pdf.pdf $>$.

Mertha, A. (2017), Stressing out: Cadre calibration and affective proximity to the CCP in Reform-era China. The China Quarterly, 229, March, 64-85.

People's Daily. “Zhonggong Zhongyang zhengzhijv changwei dao di er pi dang de qunzhongluxiang jiaoyu shijian huodong lianxi dian chuxi zhidao zhuanti minzhu shenghuohui [PSC members went to second batch contact points to attend special intra-CCP democracy seminars]" (2014, May 26), Retrieved from $<$ http://politics.people.com.cn/n/2014/0526/c1024-25062047.html>.

People's Daily. “Zhonggong zhongyang guowuyuan guanyu luoshi fazhan xin linian jiakuai nongye xiandaihua shixian quanmian xiaokang mubiao de ruogan yijian [Opinions of both the CCP central committee and the state council on the implementation of the development of new ideas about accelerating agricultural modernization to achieve the comprehensive goal of a well-off society]" (2016, January 28), People's Daily. Retrieved from $<$ http://paper.people.com.cn/rmrb/html/201601/28/nw.D110000renmrb_20160128_2-01.htm>.

Pieke, F. N. (2016). Knowing China: A twenty-first century guide. Cambridge: Cambridge University Press.

Potter, P. B. (2001). The Chinese legal system: Globalization and local legal culture. London: Routledge.

Red Cross. "Zong hui jianli dangzu chengyuan lianxi dian zhidu, dangzu chengyuan luxv fu lianxi dian diaoyan [the headquarters of the red cross established party member contact points, and the members of the party committee successfully visited contact points]" (2014, June 10), Retrieved from $<$ http://www.redcross.org.cn/hhzh/zh/newscenter/gzdt/201406/t20140610_2561 3.html>.

Ruan, B. "Genzhi houtu, qing xi baixing [Living in contact points, loving the native people]" (2014, January 26), Zhejiang Daily. Retrieved from $<$ http://zjnews.zjol.com.cn/system/2014/01/26/019831741.shtml>.

Schell, O. (1984). To get rich is glorious: China in the eighties. New York: Pantheon Books.

SGCC. "Yang Qing fu gongsi dang de qunzhong luxian jiaoyu shijian huodong lianxi dian diaoyan [Mr. Yang Qing, deputy general manager of SGCC, visited contact points in the mass line campaign]" (2014, April 28), State Grid Corporation of China. Retrieved from <http://www.hb.sgcc.com.cn/html/main/col8/201404/28/20140428110154387409963 1.html>. 
Sheehan, J. (1998). Chinese workers: A new history. London: Routledge.

State Council. "Zhonggong zhongyang bangongting guowuyuan bangongting guanyu yinfa 'nongcun jiceng ganbu lianjie lvxing zhize ruogan guiding' (shixing) de tongzhi [Notice from both the general office of the CCP central committee and the general office of the state council issuing 'regulations for rural cadres in China to perform their duties without corruption' (Interim Edition)]” (2011, May 23), State Council. Retrieved from $<$ http://www.gov.cn.gongbao/content/2011/content_1913163.htm>.

Teets, J. C. (2014). Civil society under authoritarianism: The China model. Cambridge: Cambridge University Press.

Tyson, A. \& Wu, X. (2016), Ethnic conflict and the new legalism in China. Nationalism and Ethnic Politics, 22, 4, 373-392.

Vigoda, E. (2002), From responsiveness to collaboration: Governance, citizens, and the next generation of public administration. Public Administration Review, 62, 5, $527-540$.

Wang, B. (2010), Xuexi xing dang zuzhi de jiben tezheng he jianshe lujing [The basic characteristics and constructions of party learning organizations]. Journal of Mao Zedong and Deng Xiaoping Theory, 3, 26-31.

Wang, C. 'Cong 'ti min zuo zhu' dao 'rang min zuo zhu' [from 'call the shots without the masses' knowledge or permission' to 'let the masses make their own decisions']" (2014, November 24), Xinhua. Retrieved from $<$ http://news.xinhuanet.com/mrdx/2014-10/21/c_133730576.htm>.

Wang, Q. "Shenru xuexi guanche dang de shiba da jingshen, nuli kaichuang dangfeng lianzheng jianshe he fan fubai douzheng xing jvmian [studying and implementing the decision of the party's 18th plenary session, making efforts to create a transparent government and to combat corruption]", (2013, February 26), People's Daily. Retrieved from < http://paper.people.com.cn/rmrb/html/201302/26/nw.D110000renmrb_20130226_1-02.htm>.

Wedeman, A. (2012). Double paradox: Rapid growth and rising corruption in China. Ithaca, NY: Cornell University Press.

Wei, H. \& Bei, W. "Chui jin kuang sha shi dao jin [Gold cannot be found until all the sands are blown away]", (2014, January 23), Guangxi Daily. Retrieved from $<$ http://gxrb.gxnews.com.cn/html/2014-01/23/content_925694.htm>.

Wu, B. "Hubei Hongan: gao biaozhun dingwei ba lianxi dian ban cheng shifan dian [Hongan county, Hubei province: Constructing the contact point model with high standards]", (2014, April 29), CCP News. Retrieved from $<$ http://qzlx.people.com.cn/n/2014/0429/c364565-24957602.html>.

Xinhua. "Secretive government receptions defy china's central authority", (2013, January 23), Xinhua. Retrieved from $<$ http://news.xinhuanet.com/english/indepth/2013-01/23/c_132123374_2.htm>.

Xinhua. "2013 Jiangsu shida xinwen [top ten events that happened in Jiangsu in 2013]" (2014, January 9), Xinhua. Retrieved from $<$ http://xhrb.jschina.com.cn/mp2/html/2014-01/09/content_931699.htm>. 
Xv, A. "Yu Zheng Sheng zai jing tingqu wo sheng dang de qunzhong luxian jiaoyu shijian huodong qingkuang huibao [Yu Zheng Sheng debriefs on the mass line campaign in Gansu]" (2013, December 20), Gansu Daily. Retrieved from $<$ http://epaper.gansudaily.com.cn/gsrb/html/2013-12/20/content_172100.htm>.

Yang, M. M. (1988), The modernity of power in the Chinese socialist order. Cultural Anthropology, 3, 4, 408-427.

Yang, W. "Xiang fubai liangjian, rang nongmin shuxin [showing the sword to corruption, satisfying rural farmers]" (2015, May 13), People's Daily. Retrieved from <http://media.people.com.cn/n/2015/0513/c40606-26991667.html>.

Yeh, Emily T., Kevin J. O'Brien and Jingzhong Ye. (2013), "Rural Politics in Contemporary China", The Journal of Peasant Studies 40(6), 915-928.

Yu, Fei. (2014, February 17), "Fengfu neirong, chuangxin zaiti: quanguo lianzheng wenhua jianshe lianxi dian gongzuo zongshu [Enriching the Contents, Innovating the Media: Summary of National Contact Points for Transparent Government]", China Discipline Inspection Newspaper. Retrieved from $<$ http://fanfu.people.com.cn/n/2014/0217/c141423-24380145.html>.

Zhang, B., Zhang, Z. \& Wu, H. (2016). Report on the China justice index 2015. Beijing: China University of Political Science and Law Press.

Zhang, M. \& Chen, P. (2014), "Er ling yi san nian du Zhongguo shehui dianxing quantixing shijian fenxi baogao [A research report on mass incidents in China in the first half of 2013]. Advances in Public Security in China, 2, 3-12.

Zeng, Qi. (2016), Democratic procedures in the CCP's cadre selection process: Implementation and consequences. The China Quarterly, 225 March, 73-99.

Zheng, Y. \& Chen, G. (2014), China's politics: Determined leadership and hardline Policies. East Asian Policy, 6, 1, 5-19.

Zhou, Y. (2016), "Fazhi shiye xia zhengfu yu shichang, shehui de guanxi dingwei: yi 'shichang zai ziyuan peizhi zhong qi jueding xing zuoyong' wei zhongxin de kaocha [The relationship between government, market and society: From the market perspective]. Journal of Jilin University (Social Science Edition), 2, 2734.

Zhu, J. (2008), Why are offices for sale in China? A case study of the office-selling chain in Heilongjiang province. Asian Survey, 48, 4, 558-579. 